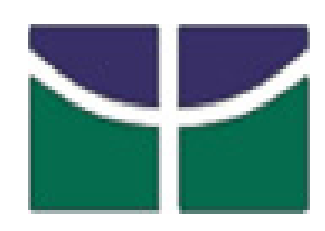

UNIVERSIDADE DE BRASÍLIA - UNB

FACULDADE DE ECONOMIA, ADMINISTRAÇÃO, CONTABILIDADE

E CIÊNCIA DA INFORMAÇÃO E DOCUMENTAÇÃO - FACE PROGRAMA DE PÓS-GRADUAÇÃO EM ADMINISTRAÇÃO - PPGA CURSO DE ESPECIALIZAÇÃO EM GESTÃO DE PROGRAMAS E PROJETOS EDUCACIONAIS

WALESKA RESENDE GONÇALVES

EDUCAÇÃO A DISTÂNCIA NO CONTEXTO DO SISTEMA UNIVERSIDADE ABERTA DO BRASIL - UAB

Brasília - DF 


\section{EDUCAÇÃO A DISTÂNCIA NO CONTEXTO DO SISTEMA UNIVERSIDADE ABERTA DO BRASIL - UAB}

Monografia apresentada no curso de Especialização em Gestão de Programas e Projetos Educacionais do Programa de PósGraduação em Administração da Faculdade de Economia, Administração, Contabilidade e Ciência da Informação e Documentação (FACE), da Universidade de Brasília, como requisito à obtenção do título de Especialista em Gestão de Programas e Projetos Educacionais.

Orientador: Prof. Dr. Bernardo Kipnis

\section{Brasília - DF


À Deus e a minha querida família apoio e motivação. 


\section{AGRADECIMENTOS}

A Deus nosso grande Amigo e Senhor Soberano. A Ele, que é a Fonte do amor, da misericórdia e do conhecimento, todo louvor.

A equipe do Sistema Universidade Aberta do Brasil - UAB, pelos dados repassados e pesquisados nos arquivos do NEAD, e pelas informações sobre o Projeto de Educação a Distância.

À minha família, pelo incentivo, colaboração e compreensão presentes durante todo o tempo. Aos meus pais, pelo orgulho e felicidade que sempre demonstraram na realização desta minha conquista.

Ao coordenador e aos professores do curso, que contribuíram brilhantemente com informações teóricas, técnicas e empíricas para o aprofundamento de novos conhecimentos.

Enfim, agradecimentos a todos que direta ou indiretamente colaboraram para a consolidação deste trabalho. 
Aprender é a única coisa de que a mente nunca se cansa, nunca tem medo e nunca se arrepende. 


\section{RESUMO}

A educação a distância vem crescendo rapidamente em todo o mundo, incentivados pelas possibilidades decorrentes das novas Tecnologias da Informação e da Comunicação. Cada vez mais cidadãos e instituições vêem nessa forma de educação um meio de democratizar o acesso ao conhecimento e de expandir oportunidades de aprendizagem ao longo da vida.E incontestável hoje a preocupação de todos em oferecer a sociedade um ensino de qualidade, com vistas a real formação do cidadão das diferentes esferas sociais e é em busca desta inclusão social e do respeito as diferenças visando a real transformação desta que governo, sociedade civil e sistemas de ensino chegam a um denominador comum sobre a necessidade de se garantir a universalização da Educação Básica e do Ensino Superior.Neste cenário é que o Sistema Universidade Aberta do Brasil visa o oferecimento de cursos à distância cuja clientela são aqueles cidadãos que não tem acesso ao ensino presencial, dandose também condições de ampliação do "acesso, permanência e sucesso" ao ensino superior neste contexto a UAB surge como uma alternativa para romper barreiras.

Palavras-chave: educação a distância, universidade aberta do Brasil, cursos a distância. 


\begin{abstract}
The education in the distance comes growing quickly in the whole world, stimulated for the decurrent possibilities of the new Technologies of the Information and the Communication. Each time more citizens and institutions see in this form of education a way to democratize the access to the knowledge and to expand chances of learning throughout the life. Undisputed E today the concern of all in offering to the society a quality education, with sights the real formation of the citizen of the different social spheres and is in search of this social inclusion and of the respect the differences aiming at the real transformation of that government, civil society and systems of education arrive at a common denominator on the necessity of if guaranteeing the universalização of the Basic Education and Ensino Superior.Em this scene is that the System Open University of Brazil aims at the oferecimento of long-distance courses whose clientele is those citizens whom access to actual education does not have, giving also conditions of magnifying of the "access, permanence and success" to superior education in this context the UAB appears as an alternative to breach barriers
\end{abstract}

Keywords: education in the distance, open university of Brazil, courses in the distance 


\section{LISTA DE SIGLAS}

ANDIFES - Associação Nacional dos Dirigentes das Instituições Federais de Ensino Superior CAPES - Coordenação de Aperfeiçoamento de Pessoal de Nível Superior CEFET - Centro Federal de Educação Tecnologica

EaD - Educação a Distância

FNDE - Fundo Nacional de Desenvolvimento da Educação

IES - Instituições Ensino Superior

IPES - Instituições Públicas de Ensino Superior

LDB - Lei de Diretrizes e Bases da Educação,

MEC - Ministério da Educação

SEED - Secretaria de Educação a Distância

UAB - Universidade Aberta do Brasil

UNESCO - Organização das Nações Unidas para a Educação 


\section{SUMÁRIO}

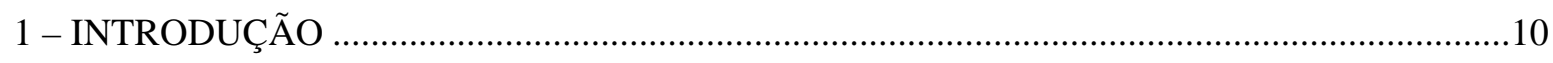

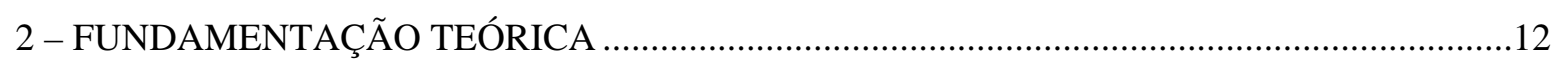

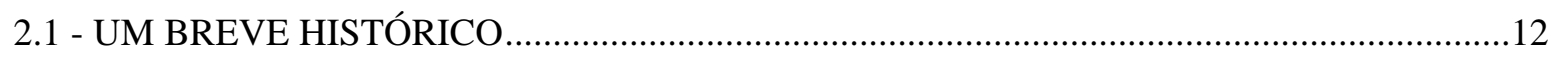

2.2 - ALGUMAS DEFINIÇÕES SOBRE EDUCAÇÃO A DISTÂNCIA .......................................13

2.3 - ELEMENTOS CONSTITUTIVOS DA EDUCAÇÂO A DISTÂNCIA ……………................16

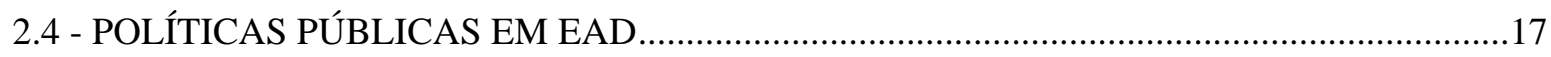

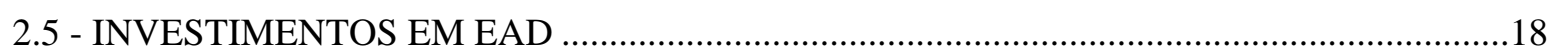

2.6 - O SISTEMA UNIVERSIDADE ABERTA DO BRASIL - UAB.............................................19

2.6.1 - INTEGRANTES DO SISTEMA UAB E SUAS COMPETÊNCIAS......................................21

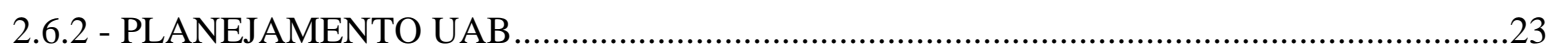

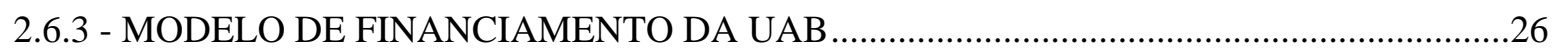

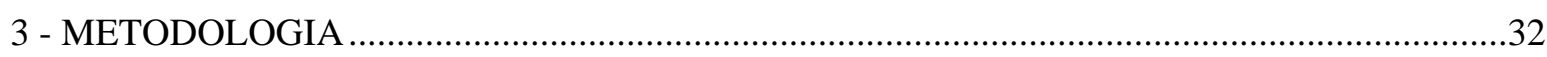

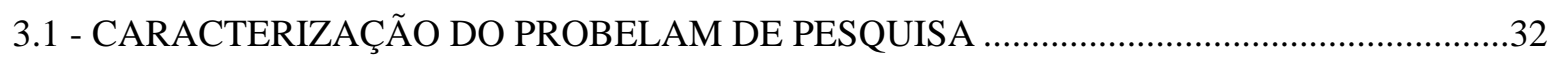

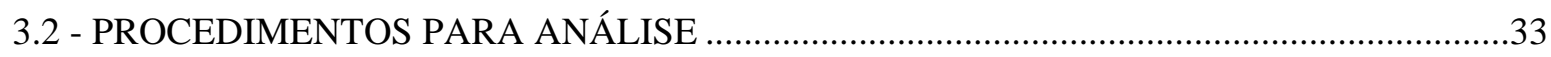

4 - APRESENTAÇÃO E ANÁLISE DOS RESULTADOS.............................................................34

4.1 - DEMANDAS DE FINANCIAMENTO DAS IES PARCEIRAS DO SISTEMA UAB ............34

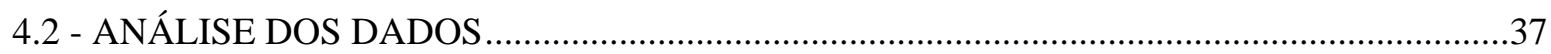

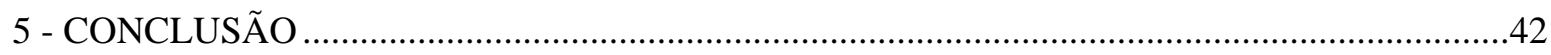

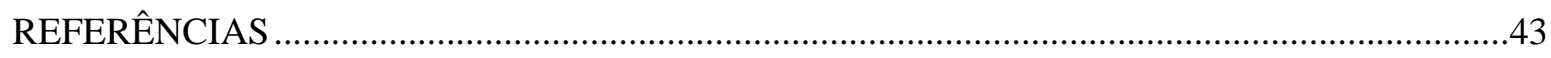

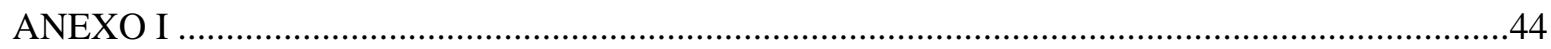




\section{1 - INTRODUÇÃO}

A educação a distância - EaD é uma modalidade educativa diferente das demais pelas especificidades que a caracteriza e a distingue. Embora não sendo uma novidade, apresenta-se hoje como uma opção eficiente, pois é capaz de atender a uma demanda por educação inicial e continuada, por democratização e interiorização do ensino, constituindo-se uma ferramenta de inclusão social.

Esta modalidade de ensino está surgindo como uma opção a mais, juntamente ao ensino presencial, por atingir um quantitativo muito grande de alunos ao mesmo tempo e também por atender a crescente demanda nacional. A EaD torna-se então um veículo que possibilita a democratização do acesso à educação em todos os níveis, aumentando os espaços educacionais

Segundo Belloni (1999),

“a educação aberta e a distância aparece cada vez mais, no contexto das sociedades contemporâneas, como uma modalidade de educação extremamente adequada e desejável para atender às novas demandas educacionais decorrentes das mudanças na nova ordem econômica mundial”.

A EaD tem se apresentado como uma alternativa para o ensino convencional não só no Brasil, mas em todo mundo. A demanda por conhecimento se intensificou com a economia globalizada e os avanços tecnológicos alcançados. Neste sentido, é criado o Sistema Universidade Aberta do Brasil - UAB, um programa de governo que visa ofertar cursos superiores a distância público, gratuito e de qualidade. Sendo oferecidos a partir das Instituições Públicas de Ensino Superior - IPES e pólos de apoio presencial localizado em vários municípios brasileiros, ambos parceiros do Sistema.

Nunes (1996) considera que:

“A EAD é um recurso de incalculável importância como modo apropriado para atender a grandes contingentes de alunos de forma mais efetiva que outras modalidades e sem riscos de reduzir a qualidade dos serviços oferecidos em decorrência da ampliação da clientela atendida”. 
A educação que se faz necessária, hoje, deverá dar condições para que o indivíduo desenvolva sua autonomia, capacidade de pensar, de resolver problemas e de tomar decisões. Isto implica em aprender a aprender, que se traduz na capacidade de refletir, analisar e tomar consciência do processo educacional.

Com o desenvolvimento de diversos instrumentos integrantes da tecnologia educacional e aliado ao progresso tecnológico, a educação a distância torna-se um veiculo que possibilita a democratização do acesso a educação em todos os níveis aumentando os espaços educacionais existentes e contribuindo com o processo democratização do ensino.

Muito se tem escrito sobre as vantagens e desvantagens de cada modalidade de ensino, seja presencial ou a distância. Sendo que os argumentos em defesa da EaD, apontam aspectos pedagógicos, flexibilidade de horários, possibilidade de atingir diversos níveis de ensino e o custo econômico desta modalidade que se torna mais barato. A EaD é uma alternativa que promete diminuir custos e atender grandes contingentes de alunos. A pesquisa proposta neste trabalho versa sobre a utilização dos diferentes recursos aplicados em cursos a distância, identificando a sua eficiência no contexto da metodologia pedagógica adotada e propondo um modelo de financiamento de cursos que abranja as necessidades da IPES e do Sistema UAB. 


\section{2 - FUNDAMENTAÇÃO TEÓRICA}

\section{1 - UM BREVE HISTÓRICO}

A Educação a Distância é uma modalidade de ensino-aprendizagem consolidada em todo o mundo e que cresce significativamente no Brasil. Vários autores afirmam que a sua origem está nas experiências de educação por correspondência, desenvolvidas a partir do século XVIII.

Litwin (2001, p.15) aponta como marco imperativo para o desenvolvimento da EAD a criação, na década de 60, da Universidade Wisconsin nos Estados Unidos e a Open University da Grã-Bretanha. A partir daí, houve um grande avanço com a institucionalização de ações voltadas para a EAD começando pela Europa e se expandindo para os demais continentes.

No Brasil, a criação da Fundação da Rádio Sociedade do Rio de Janeiro nos anos 20, do Instituto Monitor em 1939 e do Instituto Universal Brasileiro - IUB em 1941 são considerados marcos pioneiros para o desenvolvimento da EAD. As primeiras iniciativas utilizando-se da radiodifusão para a transmissão de programas educativos e o IUB oferecendo cursos supletivos e profissionalizantes por correspondência.

Mundim (2006) enfatiza que a evolução da EAD nas décadas de 50 e 60 deu-se com a explosão dos cursos por correspondência, visando a alfabetização de adultos, em parceria com a Igreja Católica. Nas décadas de 70 e 80 com a oferta dos cursos na TV, a exemplo do Telecurso de $1^{\circ}$ e $2^{\circ}$ grau oferecidos pela Rede Globo que mais tarde se transformou em Telecurso 2000. Destaca também nesse período o Programa de Ensino a Distância da Universidade de Brasília que foi reestruturado e hoje é conhecido como Centro de educação Aberta e Continuada a Distância-CEAD.

Em 1990, o Ministério da Educação em parceria com a Fundação Roquete Pinto, através da TV Educativa, lançou o Programa "Salto para o Futuro" destinado a atualização de professores e, em 1995, lança a TV Escola em rede nacional, com o objetivo de subsidiar e melhorar a qualidade do ensino.

Outra iniciativa no campo da EAD nessa década foi a criação do Curso de Pedagogia a distância, experiência pioneira no Brasil, desenvolvida a partir de 1995 pela Universidade Federal do Mato Grosso em parceria com a Universidade Estadual e a Secretaria Estadual de Educação e com o apoio da Tele-Université de Quebec, Canadá, visando a formação superior dos professores dos anos iniciais do ensino fundamental daquele Estado. 
Por outro lado, a criação da Secretaria de Educação a Distância, em 1995, na estrutura do Ministério da Educação pode ser também considerado um importante passo para favorecer o desenvolvimento de ações governamentais voltadas para a o fortalecimento da EAD. Além disso, a implantação de uma rede de internet global e integrada, abrangendo todo tipo de uso, deu abertura para uma nova mediação do processo ensino-aprendizagem agregando valores a EAD, redirecionando as práticas educativas e ampliando novas perspectivas para o seu campo de atuação.

Face ao exposto, pode-se afirmar que o Brasil não esteve totalmente alheio à evolução da EAD. No entanto, essas experiências desenvolvidas através de iniciativas governamentais ou privadas, com maior ou menor sucesso, não foram suficientes para consolidar a EAD no cenário educacional.

A forte vinculação ao ensino técnico, a idéia de formação aligeirada, a implantação de sistemas provisórios isolados da educação em geral aliados à falta de uma legislação que estabelecesse normas claras e específicas deram ênfase aos preconceitos, críticas e resistências a esta modalidade de ensino, freando o seu desenvolvimento e impedindo, portanto, que acompanhasse os mesmos ritmos de evolução de outros países do mundo.

Entretanto, a realidade brasileira vem mudando significativamente e a implementação de novas políticas educacionais, a partir do final dos anos 90, apontam um caminho mais favorável para expansão, qualidade e democratização do acesso a EAD para as diferentes camadas da população.

\section{2 - ALGUMAS DEFINIÇÕES SOBRE EDUCAÇÃO A DISTÂNCIA}

A legislação brasileira define a Educação a Distância - EaD uma conotação bem abrangente, possível de englobar as múltiplas definições na medida em que coloca que:

Educação a distância é uma forma de ensino que possibilita a auto-aprendizagem, com a mediação de recursos didáticos sistematicamente organizados, apresentados em diferentes suportes de informação, utilizados isoladamente ou combinados, e veiculados pelos diversos meios de comunicação. (Diário Oficial da União decreto ${ }^{\circ}$ 2.494, de 10 de fevereiro de 1998)

A EaD, embora não sendo uma novidade, apresenta-se como uma opção eficiente, pois é capaz de atender a uma demanda por democratização da educação e constitui-se, para o universo educacional, uma conseqüência da modernidade. 
A educação a distância funciona, como a modalidade presencial, as duas modalidades só serão eficientes se praticadas de maneira sistemática, freqüente e organizada. Mas, a educação a distância, segundo Rocha e Martins (2000), tem especificidades como a separação do professor e aluno; o controle do aprendizado que é realizado muito mais intensamente pelo aluno do que pelo professor e que se apoia em alguma forma de tecnologia.

Concordando com Guitierrez e Prieto (1994, p.9), “ a educação presencial é uma modalidade presa ao ensino com objetivos preestabelecidos e a EaD passa a ser uma outra modalidade caracterizada pela aprendizagem, pela participação e pela construção do conhecimento".

Tendo em vista as características apresentadas, a educação a distância desponta como uma alternativa importantíssima para a educação continuada, essencial à sobrevivência profissional no mercado de trabalho competitivo atual. Para Turlington (2000), a escolha pela educação a distância é interessante, pois o profissional não precisa deixar emprego ou casa para ter acesso à capacitação, sendo também opção ideal para os adultos que desejam retomar seus estudos.

A EaD, segundo Belloni (1999), é entendida como uma modalidade de educação capaz de atender às novas demandas educacionais em função das mudanças sociais. Com o desenvolvimento de novas tecnologias e de uma sociedade cujas principais características são a quantidade e a velocidade de transmissão das informações, resultando em uma relativização das barreiras entre os países e a cultura, a educação deve ser repensada com o intuito de atender às exigências desse novo cenário.

Para Dohmem (1967), a Educação a Distância é uma forma sistemática e organizada de auto-estudo, onde o aluno se instrui a partir do material de estudo que Ihe é apresentado, onde o acompanhamento e a supervisão do sucesso do estudante são levados a cabo por um grupo de professores. Isto é possível de ser feito a distância através da aplicação de meios de comunicação capazes de vencer longas distâncias.

Com relação ao uso das tecnologias, Landim (1997) diz que: a educação a distância pressupõe a combinação de tecnologias convencionais e modernas que possibilitam o estudo individual ou em grupo, nos locais de trabalho ou fora, por meio de métodos de orientação e tutoria a distância, contando com atividades presenciais específicas, como reuniões do grupo para estudo e avaliação.

A Lei de Diretrizes e Bases da Educação (LDB), lei número 9394 de 20/12/1996, no seu artigo 80 oficializou a $\mathrm{EaD}$ no Brasil, sendo regulamentada pelo decreto 2494 de10/02/1998, que em seu artigo primeiro assim define: 
“A Educação a Distância é uma forma de ensino que possibilita a auto-aprendizagem com a mediação de recursos didáticos sistematicamente organizados, apresentados em diferentes suportes de informação, utilizados isoladamente ou combinados, e veiculados pelos diversos meios de comunicação”.

Diversos autores, nas mais variadas publicações, buscaram conceituar a educação a distância. Para deixar mais clara e fundamentada essa questão, apresenta-se a seguir alguns conceitos.

Para Aretio (1994) a EaD pode ser entendida como:

“Sistema tecnológico de comunicação bidirecional, que pode ser massivo e que substitui a interação pessoal, na sala de aula, de professor e aluno, como meio preferencial de ensino, pela ação sistemática e conjunta de diversos recursos didáticos e pelo apoio de uma organização e tutoria que propiciam a aprendizagem independente e flexível dos alunos”.

Segundo Preti (1996) a EaD pode ser definida como:

“Uma alternativa pedagógica de grande alcance e que deve utilizar e incorporar as novas tecnologias como meio para alcançar os objetivos das práticas educativas implementadas, tendo sempre em vista as concepções de homem e sociedade assumidas e considerando as necessidades das populações a que se pretende servir (...) Deve ser compreendida como uma prática educativa situada e mediatizada, uma modalidade de se fazer educação, de se democratizar o conhecimento. É portanto, uma alternativa pedagógica que se coloca hoje ao educador que tem uma prática fundamentada em uma racionalidade ética, solidária e compromissada com as mudanças sociais”.

Considerando os conceitos acima expostos Landim (1997) levanta os seguintes objetivos da Educação a Distância: democratizar o acesso à educação; propiciar uma aprendizagem autônoma e ligada à experiência; promover um ensino inovador e de qualidade; 
incentivar a educação permanente e reduzir os custos. A autora ainda destaca as seguintes vantagens desta modalidade de ensino: a abertura, a flexibilidade, a eficácia, a formação permanente e pessoal e a economia.

Segundo Preti (2000, p.126), a EaD é uma modalidade embasada em teorias, concepções e metodologias que também dão sustentação à educação presencial, e considera importante enfatizar que trata-se de uma modalidade e não uma metodologia, para não cair-se na crença de que é um campo totalmente diferente, num sistema de educação paralela, substitutivo ao que já existe.

\section{3 - ELEMENTOS CONSTITUTIVOS DA EDUCAÇÂO A DISTÂNCIA}

São pois, elementos constitutivos da Educação a Distância (EAD):

- A separação física entre professor e aluno, o que o distingue do ensino presencial. Ou seja, a presença física do professor ou do interlocutor com que o estudante vai dialogar não é necessária e indispensável para que se dê a aprendizagem;

- O estudo individualizado e independente : reconhece-se a capacidade do estudante de construir seu caminho, seu conhecimento por ele mesmo;

- O uso da tecnologia : os recursos técnicos de comunicação, que hoje tem alcançado um avanço espetacular (correio, rádio, TV, audio, hipermídia interativa, internet ), permitem romper com as barreiras das distâncias, das dificuldades de acesso à educação e dos problemas de aprendizagem por parte dos alunos que estudam individualmente, mas não isolados e sozinhos. Oferecem possibilidades de se estimular e motivar o estudante, de armazenamento e divulgação de dados, de acesso as informações mais distantes e com uma rapidez incrível;

- A comunicação bidirecional: o estudante se beneficia de um diálogo, não é um mero receptor de informações, de mensagens. Apesar da distância se estabelece na EAD relações dialogais, criativas, críticas e participativas.

- O processo de ensino-aprendizagem mediatizada: a EAD deve oferecer suportes e estruturar um sistema que viabilizem e incentivem a autonomia dos estudantes nos processos de aprendizagem. E isso acontece predominantemente através do tratamento dados aos conteúdos e formas de expressão mediatizados pelos materiais didáticos, meios tecnológicos, sistema de tutoria e de avaliação (Preti, 1996). 


\section{4 - POLÍTICAS PÚBLICAS EM EAD}

O poder público tem o desafio de propiciar condições de acesso a educação com a implementação de políticas públicas que atendam aos interesses e demandas da população. Em outubro de 1998, na Conferência Mundial sobre Ensino Superior da UNESCO Organização das Nações Unidas para a Educação, Ciência e Cultura, afirmou-se que a Educação a Distância pressupõe tecnologia, investimentos e criatividade e pode suprir uma grande parte da população carente de estudos.

Belloni (1999, p.49) afirma que a educação, desde o início da modernidade tem sido considerada com elemento essencial de construção do Estado-Nação, vai se transformando cada vez mais em mercadoria exportável sob diversas formas, inclusive como aprendizagem aberta e a distância.

Neste sentido torna-se fundamental a criação de políticas públicas de Estado, a fim de garantir educação para todos, alocando recursos em Instituições Públicas de Ensino já que a demanda para a educação e crescente. O papel da Universidade Pública é citada por Prado (2000), em artigo publicado pela Folha de São Paulo, onde a autora afirma que o Estado não pode deixar de ser o mantenedor do ensino público universitário. A universidade não pode ser confundida com uma empresa que atende prioritariamente o lucro. Não deve separar produção do saber do mundo social e da política, mas voltar-se para as necessidades das sociedades em que está encravada.

A Constituição Federal artigo 208, inciso V, determina: " o dever do Estado com a educação será efetivado mediante garantia de acesso a níveis mais elevados de ensino". O Ministério da Educação - MEC desenvolve políticas públicas para o desenvolvimento da educação, perpassando todos os níveis do ensino básico a pós - graduação.

Neste propósito nos últimos anos as políticas públicas têm se voltado para disseminar o conhecimento utilizando à modalidade a distância como uma ferramenta fundamental para democratizar a oferta e acesso a educação superior pública no Brasil. Políticas Públicas pensadas para disseminar cursos superiores na modalidade a distância, para formação de professores aceleraram os processos de disseminação da EaD. Programas como PróLicenciatura e Pro formação, são exemplos da ação do Governo Federal no sentido de articular vários setores as esfera pública.

Em 2005 com a formulação do Projeto Piloto criado no âmbito da ANDIFES e do Fórum das Estatais, proporcionou a disseminação do curso de Administração a distância em diferentes estados brasileiros. A partir deste projeto foi criado o Programa Universidade 
Aberta do Brasil com o propósito inicialmente de ofertar cursos superiores públicos nas diversas áreas do ensino.

\section{5 - INVESTIMENTOS EM EAD}

Para a introdução da EaD nas Universidades Públicas é necessário um forte investimento governamental, não só na aquisição da tecnologia mas também, e principalmente, na reciclagem do corpo docente. Belloni afirma:

"Uma outra tendência significativa é evidentemente o investimento em tecnologias, não apenas em equipamentos, mas também na pesquisa de metodologias adequadas e na formação para seu uso como ferramenta pedagógica. A necessidade de investimentos importantes nesta área é crucial, pois trata-se de investimentos iniciais elevados e benefícios de médio e longo prazo".

Embora tenham se reduzido bastante nos últimos anos, ainda é alto o custo da EaD. Na Conferência Mundial sobre Ensino Superior da UNESCO Frederico Mayor, diretor-geral daquela organização comenta que os custos de infra-estrutura, hardware, software e treinamento de pessoal são mutilantes para os países menos ricos, cujas aspirações de modernidade já estão minadas pela luta pela sobrevivência. Ou seja, aquilo que seria a panacéia para os elevados custos da universidade tradicional pode ser mais um elemento da crescente má distribuição de renda, informação e conhecimento entre ricos e pobres.

Dentro da perspectiva do custo-benefício, a EaD corre o risco de transformar a educação numa questão de mercado, causando sérios riscos na formação do jovem universitário. Belloni (1999) afirma que a expansão da EaD na última década representa muito menos o "triunfo da ideologia do acesso aberto" à educação e muito mais o impacto das forças de mercado e da situação de recessão econômica e conseqüentes políticas governamentais de restrição de recursos aplicados à educação. Neste contexto, a EaD aparece ao mesmo tempo como uma solução e como uma ameaça.

A falta de investimento governamental já sentida no ensino presencial pode criar uma distorção mais série quando se trata da EaD. Não se deve tratar a questão educacional com a lógica do mercado, principalmente na Universidade Pública, em função da sua responsabilidade social. Gilberto Dimenstein, em artigo publicado na Folha de São Paulo 
(1999), comenta que importantes universidades norte-americanas já montam convênios no Brasil, oferecendo cursos à distância e que, com essa competição, quem corre sério risco são as universidades públicas, com suas monumentais crises de financiamento e armadilhas burocráticas.

O papel da Universidade Pública é destacado pela professora Maria Lígia Coelho Prado (2000), em artigo publicado pela Folha de São Paulo :

"[...] o Estado não pode deixar de ser o mantenedor do ensino público universitário. A universidade não pode ser confundida com uma empresa que atende prioritariamente o lucro. Não deve separar produção do saber do mundo social e da política, mas voltar-se para as necessidades das sociedades em que está encravada."

"Precisa se preocupar com a produção do conhecimento prático aplicado, mas também

com o saber teórico, base da reflexão consistente. É fundamental que a formação de seus alunos seja abrangente, tornando-os competentes profissionais e cidadãos críticos comprometidos com a solução dos problemas das sociedades latino-americanas".

\section{6 - O SISTEMA UNIVERSIDADE ABERTA DO BRASIL - UAB}

O Sistema Universidade Aberta do Brasil - UAB - é um programa do Ministério da Educação criado, em 2005, no âmbito do Fórum das Estatais pela educação. Esse Fórum, coordenado pelo Ministro Chefe da Casa Civil e o Ministro da Educação com a participação efetiva das empresas estatais brasileiras, buscava potencializar as políticas públicas para uma educação inclusiva e cidadã visando a construção de um novo modelo de desenvolvimento para o país.

Nessa perspectiva, a UAB surge e é regulamentada pelo Decreto $\mathrm{n}^{0} 5.800$ de 8 de junho de 2006, não como uma instituição tradicional, mas como um sistema nacional que tem como principal objetivo estimular a articulação e integração da educação superior na modalidade a distância, visando expandir e interiorizar a educação superior nos pólos municipais de apoio presencial com a implementação de cursos das mais diversas áreas e prioritariamente voltados para a capacitação de professores da educação básica.

Trata-se de um projeto inovador desenvolvido em parceria com as instituições federais de ensino, os Estados e Municípios tendo em vista atender a demanda por uma educação de qualidade para os municípios brasileiros, que não possuem cursos de formação superior ou cujos cursos ofertados não são suficientes para atender a todos os cidadãos. Nesse sentido, 
apesar ter sido criado com o intuito principal de qualificar professores de educação básica, podem participar do Sistema Universidade Aberta do Brasil qualquer cidadão que tenha concluído a educação básica, e que, tenha sido aprovado em processo seletivo, atendendo aos requisitos exigidos pela instituição pública, vinculada ao Sistema UAB, ofertante do curso.

A Resolução 24 de 06 de junho de 2008, regulamenta o repasse de recursos da UAB, define o programa em seu Art. $2^{\circ}$ como o Sistema Universidade Aberta do Brasil cumprirá suas finalidades e objetivos sócio-educacionais em regime de colaboração da União com entes federativos, bem como a partir da articulação entre as instituições públicas que ministram ensino de nível superior e os estabelecimentos de apoio presencial, denominados pólos.

A resolução 44 de 29 de dezembro de 2006 define em seu a Art. $2^{\circ}$ que o Sistema Universidade Aberta do Brasil - UAB está voltado para o desenvolvimento da modalidade de educação a distância, com a finalidade de expandir e interiorizar a oferta de cursos e programas de educação superior no País.

A resolução 24 no Art. $3^{\circ}$ regulamenta que a UAB Viabilizara cursos de licenciatura para a formação inicial e continuada de professores para a educação básica e, ainda, a participação de professores e técnicos das IPES em projetos de pesquisa e de desenvolvimento de metodologias educacionais por meio de assistência financeira as IPES. Obedecendo às seguintes diretrizes:

I. oferecer, prioritariamente, cursos de licenciatura e de formação inicial e continuada de professores da educação básica;

II. oferecer cursos superiores para capacitação de dirigentes, gestores e trabalhadores em educação básica dos Estados, do Distrito Federal e dos Municípios;

III. oferecer cursos superiores nas diferentes áreas do conhecimento;

IV. ampliar o acesso à educação superior pública;

V. reduzir as desigualdades de oferta de ensino superior entre as diferentes regiões do País;

VI. estabelecer amplo sistema nacional de educação superior a distância; e VII. fomentar o desenvolvimento institucional para a modalidade de educação a distância, bem como a pesquisa em metodologias inovadoras de ensino superior apoiadas em tecnologias de informação e comunicação.

Mota, Chaves e Cassiano (2006, p.19-22) reconhecem a relevância do Projeto UAB enquanto programa de Nação que tem o desafio de propiciar educação superior com qualidade e democracia e fomentar a construção de um projeto nacional sustentável e inclusivo. 
Afirmam que esse grande movimento nacional, das instituições e das demais esferas governamentais, em torno da democratização da educação superior representa um marco histórico para a educação brasileira, por se tratar de uma iniciativa coletiva compatível com a necessidade de revigoramento de um novo modelo de formação superior que possibilita o repensar da educação ao longo da vida, considerando-se a emergência de novas competências para o trabalho e a vida social instituídas pelos constantes avanços tecnológicos.

O MEC lançou entre os anos de 2005 e 2006 editais públicos para a convocação de representantes dos Municípios, Estados e Distrito Federal apresentarem propostas de pólo municipal de apoio presencial e para as instituições federais para apresentarem propostas de cursos superiores a distância que serão vinculados a esses pólos.

Assim, foram selecionadas 74 instituições para a oferta de cursos em 586 pólos dos municípios brasileiros - os quais aportam o espaço com infra-estrutura física, tecnológica e de recursos humanos adequadas para atender tanto as necessidades das instituições de ensino ofertantes dos cursos, quanto às necessidades dos estudantes.

O Sistema UAB, pioneiro no país, tem por objetivo estabelecer cerca de 800 pólos de apoio presencial no território nacional. É, portanto, um projeto grandioso, cujos esforços empreendidos visam garantir o seu caráter permanente, o que vai contribuir eficazmente para democratizar o ensino superior gratuito e de qualidade no país.

Moran (2007, p.10-14)) afirma que no Brasil muitas universidades estão se capacitando para trabalhar com a EAD. Considera que a implantação do Sistema Universidade aberta do Brasil se configura como uma etapa de amadurecimento da educação a distância, de legitimação e consolidação de instituições competentes. No entanto, ressalta a importância da aproximação entre os núcleos de EAD nas instituições com os demais departamentos e grupos para o desenvolvimento de experiências que integram o virtual e o presencial garantindo a aprendizagem significativa.

\subsection{1 - INTEGRANTES DO SISTEMA UAB E SUAS COMPETÊNCIAS}

A UAB não é uma instituição de ensino, é um programa de governo que em seu decreto é definido como Sistema Universidade Aberta do Brasil - UAB, que fomenta instituições públicas de ensino parceiras na oferta de cursos a distância. Conforme a resolução $\mathrm{n}^{\circ} 44$ do Fundo Nacional de Desenvolvimento da Educação - FNDE o Sistema UAB tem como participantes: 
A CAPES, com apoio da Secretaria de Educação a Distância - SEED, responsáveis pela articulação e gestão do Sistema UAB - que terão as seguintes competências:

a) colaborar com os demais integrantes do Sistema UAB para a organização e divulgação do Cadastro Permanente de Professores cursistas, cadastro de professores e pesquisadores, tutores e coordenadores de pólos, para os quais serão concedidas as bolsas de estudo e pesquisa de que trata esta Resolução;

b) monitorar, analisar e registrar mensalmente os Relatórios de Ocorrências encaminhados pelas Instituições de Ensino Superior - IES, relativos à permanência, interrupção ou cancelamento do pagamento das bolsas;

c) encaminhar a autorização de pagamento de bolsas ao FNDE, bem como solicitar sua interrupção e cancelamento;

d) instituir Comissão de Acompanhamento designada por Portaria Ministerial, definindo suas atribuições;

e) instituir, em cooperação com as IES participantes da UAB, os manuais de atribuições e obrigações relativas às funções previstas para os bolsistas;

f) definir, em conformidade com as diretrizes do programa, os critérios para seleção dos bolsistas a serem aplicados pelos Sistemas de Ensino.

As Instituições Públicas de Ensino Superior - IPES terão as seguintes obrigações:

a) formalizar a sua participação nos programas aprovados para a UAB, por meio da assinatura de Acordo de Cooperação Técnica;

b) quando se tratar de instituição federal, apresentar ao FNDE plano de trabalho simplificado, na forma prevista na Resolução CD/FNDE n ${ }^{0}$ 19, de 13 de maio de 2005 e no Decreto $n^{\circ}$ 6.170, de 25 de julho de 2007;

c) garantir à CAPES e ao FNDE acesso a todas as informações pertinentes à implementação do objeto do convênio ou do PTA simplificado, colaborando com o trabalho de acompanhamento e avaliação;

d) estruturar os cursos destinados à formação continuada, a serem oferecidos aos professores formadores e tutores que abordem aspectos teóricos e operacionais, como: educação a distância, conceitos, estrutura, metodologia e proposta pedagógica do Sistema $\mathrm{UAB}$.

Os Pólos de apoio presencial que funcionam como pontos de apoio Presencial. São espaços físicos mantidos por municípios ou governos de estado que oferecem infra-estrutura física, tecnológica e pedagógica para que os alunos possam acompanhar os cursos UAB. Os 
pólos estão estrategicamente localizados em microregiões e municípios com pouca ou nenhuma oferta de educação superior.

A proposta de criação de um Pólo Municipal de Apoio Presencial parte do próprio município ou governo de estado que enviam projetos conforme abertura de Edital. Estes projetos apresentam detalhes de infra-estrutura física, logística de funcionamento, descrição de recursos humanos para o pólo funcionar, bem como uma lista dos cursos superiores pretendidos para o município, com respectivos quantitativos de vagas.

\subsection{2 - PLANEJAMENTO UAB}

Após vários encontros regionais de coordenadores onde foram discutidos vários pontos da UAB chegou a conclusão de o Sistema Esta formado da como segue:

1. Natureza dos cursos financiados pelo MEC

Os recursos federais da UAB serão voltados para a formação de professores para a educação básica;

2. Natureza dos cursos financiados pelos Estados

Os Estados poderão acrescentar recursos estaduais para a oferta de outros cursos de interesse do desenvolvimento local;

3. $\quad$ Os cursos são permanentes

Serão ofertadas vagas de forma contínua nos pólos de apoio presencial, até o atendimento da demanda local.

Uma vez iniciada a primeira oferta de um cursos em um determinado pólo, ambos aprovados em edital, as IES poderão fazer automaticamente novos exames de ingresso nestes cursos e pólos contando com a garantia dos recursos do MEC. Estes exames de ingresso poderão ter uma ou duas entradas anuais. Visando a otimização dos recursos, a periodicidade na oferta de disciplinas estará relacionada com a escolha entre uma ou duas entradas:

- Duas entradas anuais: neste caso a Universidade poderá oferecer a mesma disciplina duas vezes por ano, atendendo aos alunos que cursam essas disciplinas pela primeira vez e, também, aos alunos repetentes;

- Uma entrada anual: neste caso a Universidade poderá oferecer a mesma disciplina apenas uma vez por ano atendendo aos alunos que cursam essas disciplinas pela primeira vez 
e, também, aos alunos repetentes. Esta opção, do ponto de vista do aluno repetente, poderá acarretar dificuldades para o seu progresso nos estudos.

4. Os cursos terão qualidade acadêmica

Será exigida inequívoca qualidade acadêmica dos cursos. Os cursos que não estiverem bem colocados no SINAES terão os exames de ingresso suspensos, mantendo-se o financiamento até a conclusão das turmas já existentes.

5. Desenho regional para a oferta dos cursos de graduação e especialização:

Oferta de cursos de graduação: será realizada preferencialmente no âmbito Estadual. As Instituições deverão ofertar cursos de graduação em pólos localizados em seu Estado sede, exceto nos casos de pólos que estejam em Estados vizinhos, com localização mais próxima da IES em questão. Este modelo otimiza recursos e incrementa a qualidade na oferta dos cursos, uma vez que cursos de graduação, principalmente na área e formação de professores, necessitam de grande número de atividades presenciais realizadas no pólo, como por exemplo, as práticas de laboratório e os estágios supervisionados. Além disso, esta medida favorece o estabelecimento de parcerias entre governos estaduais e municipais para a sustentabilidade financeira do pólo.

Oferta de cursos de especialização: será realizada no âmbito regional, com um modelo de oferta com menor necessidade de apoio presencial, uma vez que é destinada a um público alvo já graduado. Esse desenho permite desenvolver o conceito da casa do professor, com estimativa de oferta, em cada pólo, de cerca de 10 cursos de especialização dedicados à formação continuada de professores. Em cada região geográfica brasileira, as IES deverão realizar um planejamento estratégico para que as atividades de apoio presencial, previstas nos cursos, possa ser apoiada pela IES localizada mais perto de cada pólo.

6. Novos cursos em pólos já existentes

Serão realizadas chamadas para as IES oferecerem novos cursos de formação inicial e continuada de professores em pólos de apoio presencial em operação.

7. Financiamento das atividades dos pólos de apoio presencial

i. $\quad$ tutoria presencial: custeada pelo MEC;

ii. coordenador do pólo: custeada pelo MEC;

iii. computadores: custeados pelo MEC;

iv. conexão em banda larga: custeada pelo MEC;

v. livros para as bibliotecas: custeada, em parte, pelo MEC;

vi. construção ou adaptação dos imóveis sede dos pólos de apoio presencial: custeada pelos governos Estadual e/ou Municipal; 
vii. mobiliário para os pólos: custeada pelos governos Estadual e/ou Municipal;

viii. laboratórios didáticos (exceto informática): custeada pelos governos Estadual e/ou Municipal;

ix. manutenção de serviços de vigilância e limpeza: custeada pelos governos Estadual e/ou Municipal;

x. energia elétrica, telefonia e água: custeada pelos governos Estadual e/ou Municipal;

8. funcionários técnico e administrativos do pólo, inclusive os técnicos dos laboratórios didáticos: custeada pelos governos Estadual e/ou Municipal; Financiamento das atividades nas IES

9. Custeadas pelo MEC, são definidas em uma planilha acordada entre o MEC e a IES a partir dos projetos político-pedagógicos de cada curso, em função de parâmetros prédefinidos pela UAB.

10. Localização dos Pólos de apoio presencial

A UAB tem por objetivo estabelecer cerca de 800 pólos de apoio presencial no território Nacional (o número é em função de maximizar os recursos globais de 1 bilhão de reais quando do funcionamento integral do sistema em 2011)

A escolha dos municípios sede dos pólos será realizada da seguinte forma:

i Serão respeitadas as escolhas dos 291 pólos de apoio presencial realizadas no primeiro edital da UAB;

iii. Considerando as 558 microrregiões do Brasil definidas pelo IBGE, com o apoio dos coordenadores da UAB nos Estados, algumas microrregiões serão subdivididas, oferecendo cerca de 750 microrregiões finais. Nesta subdivisão, devem ser consideradas, prioritariamente, a densidade de concluintes do ensino médio, o número de professores da rede pública, o acesso entre cidades da microrregião, a ausência de oferta de curso superior por IES pública e o IDEB da microrregião;

iv. Das 750 microrregiões finais, serão retiradas aquelas que contêm um ou mais pólos do primeiro edital da UAB, restando $\mathrm{N}$ microrregiões;

v. Destas N microrregiões será considerada a oferta já iniciada de cursos dos programas Pró-licenciatura realizados por IES públicas com cursos bem avaliados e pólos em parcerias com prefeituras Municipais, restando M microrregiões; 
vi. Destas $\mathrm{M}$ microrregiões, serão selecionadas, por meio do segundo edital da UAB, em cada microrregião, os pólos de apoio presencial melhor avaliados, restando J microrregiões não contempladas;

vii. Estas J microrregiões serão objeto do terceiro edital da UAB.

\subsection{3 - MODELO DE FINANCIAMENTO DA UAB}

No inicio de 2007 os técnicos da então Coordenação Geral da UAB, começou a pensar em um modelo de financiamento de cursos superiores a distância. O primeiro modelo foi proposto após analise de especialistas em EaD que atuavam na UAB até então, o modelo foi pensado para atender as principais demandas das Universidades e agregar um custo aluno de $\mathrm{R} \$ 1.800,00$ (hum mil e oitocentos reais) por curso.

Com a Estruturação do Sistema Universidade do Brasil - UAB em 2008, foi criada a Coordenação Geral de Supervisão e Fomento, cujo objetivo principal é definir parâmetros de financiamento, gerenciar a execução dos recursos financeiros, aprovar, acompanhar e fiscalizar os projetos que promovam a implantação e implementação da educação à distância nas instituições públicas de ensino superior, atender as demandas do Sistema Geral de Bolsas - SGB, cadastrando e autorizando o pagamento de bolsistas no âmbito do Sistema Universidade Aberta do Brasil - UAB, orientar os coordenadores UAB em suas necessidades referentes à Coordenação. Esta coordenação e a responsável pela analise das planilhas financeiras de oferta dos cursos encaminhadas pelas IES. Neste sentido foi necessário adequar o modelo de financiamento existente na UAB, utilizando parâmetros a serem seguidos para todas as instituições participantes.

A planilha orçamentária foi dividida em Ações financiáveis onde o calculo seria adequado ao Curso seja ele graduação, especialização ou aperfeiçoamento e ao Núcleo de $\mathrm{EaD}$ da instituição. Tendo em vista que alguns financiamentos influenciariam indiretamente em cada curso da instituição independente do quantitativo de cursos ofertados só teria uma planilha orçamentária para atender as demandas do Núcleo.

Abaixo esta descrito o modelo de financiamento com sua Ações e funções correspondentes. È valido lembrar que este modelo de financiamento de cursos só agrega recursos de Custeio, o Sistema UAB utiliza-se dos recursos físicos e humanos da IES e Pólos Parceiros, sendo que os docentes integrantes do Sistema recebem bolsa de pesquisa para evolução do projeto. 
Ação 01 - Visita de Oferta do Cursos:

Esta Ação foi definida para que as Instituições na figura do Coordenador UAB e do Coordenador de Curso pudessem ir ao Pólo, antes do inicio dos cursos, verificar se o Pólo teria a infra-estrutura e as condições para oferta do curso imediato ou se haveria alguma necessidade de adequação. Os itens financiados nesta Ação são diárias, passagens e material de consumo.

\section{Ação 02 - Oferta do Curso}

Esta Ação contempla todas as despesas com a oferta do curso nos pólos, sendo que o financiamento é de até 04 encontros presenciais por semestre para cada curso em cada pólo. Para que estes encontros aconteçam é essencial o pagamento de diárias, passagens, combustível, aluguel de veículos, material de consumo, postagem e reprografia. É disponibilizado nesta ação a aquisição de bibliografia para apoiar os tutores na execução do curso durante os semestres, sendo financiado 2 livros por disciplina.

Tendo em vista a demanda dos cursos à distância e quantidade de alunos a serem atendidos, financiamos o pagamento de serviços de terceiros pessoa física para apoiar as coordenações de cursos as funções sugeridas para este financiamento são: apoio administrativo, secretária e auxiliar de informática.

\section{Ação 03 - Produção e Reprodução do Material Didático}

A UAB percebe a Educação a Distância, como uma forma dinâmica de ensino, que possibilita a auto-aprendizagem através de diversos recursos didático-pedagógicos organizados, estruturados e apresentados em diferentes suportes de informação, que podem ser utilizados isoladamente, ou ainda de forma combinada. Nesta ação o financiamento foi formulado no sentido de reproduzir todo o material pedagógico do curso, assim o pagamento de material de consumo e de serviços de terceiros pessoa jurídica que estão diretamente associados a reprodução do material didático, quanto a produção nesta ação é financiada a produção de vídeo-aula para apoio aos cursos, mídias flash para um material mais dinâmico e estruturação do ambiente virtual de aprendizado. 
Ação 04, 05,06 e 07 - Seleção e Capacitação de Tutores.

Estas Ações são divididas em quatro etapas distintas a seleção de tutores presenciais e a distância e a capacitação dos mesmos. Na seleção de tutores a distância o único gasto é para material de consumo, na seleção de tutores presenciais há necessidade da visita de professores nos pólos de ensino presencial, para promover o processo seletivo de tutores. Nesta seleção há o financiamento de diárias, passagens e material de consumo.

Quanto a capacitação de tutores a proposta é de que os mesmos sejam capacitados na Universidade de Ensino, para que haja uma maior interação dos agentes envolvidos no processo, assim o financiamento para os tutores a distância o gasto é somente com material de consumo e para os tutores presencias há necessidade de diárias passagens e material de consumo.

$$
\text { Ação } 08 \text { - Bolsas }
$$

A definição no pagamento de bolsas inicialmente seguiu o padrão da resolução aprovada em 2006 o financiamento em 2008 agregou algumas solicitações das IES. Abaixo esta listado as funções relacionadas a bolsas financiadas pela UAB. O pagamento destas bolsas é regulamentado pela resolução CD/FNDE nº 44 de 29 de dezembro de 2006 que estabelece orientações e diretrizes para a concessão de bolsas de estudo e de pesquisa a participantes dos cursos e programas de formação superior, no âmbito do Sistema Universidade Aberta do Brasil. As principais regulamentações desta resolução são:

- $\quad$ Apresentação das diretrizes do Sistema UAB, seus participantes e suas competências;

- $\quad$ Orientações sobre a concessão e do pagamento das bolsas;

- Regulamentação das obrigações e os deveres dos professores formadores, supervisores de curso e tutores no programa;

\section{1 - Coordenador UAB e Adjunto}

A figura do Coordenador UAB é muito importante pois ele tem a função de articulação entre o Sistema UAB e a Universidade, no sentido de apoiar as coordenações de curso que ofertam ou pretendem ofertar cursos a distância. O Coordenador também é 
responsável pela homologação de todos os bolsistas vinculados a IES e por gerar todo e qualquer tipo de relatório referentes ao financiamento feito a Universidade, acompanhamento dos pólos de apoio presencial e disseminação da cultura de EaD. O Coordenador Adjunto seria um suplente do Coordenador UAB apoiando em todos os processos. A função destes coordenadores esta definida na resolução como agentes que atuarão nas atividades de coordenação e apoio aos pólos presenciais, e no desenvolvimento de projetos de pesquisa relacionados aos cursos e programas implantados no âmbito do Sistema UAB Tanto o Coordenador UAB quanto o Adjunto são de escolha do Dirigente máximo da IES.

\section{2 - Coordenador de Curso}

O coordenador de curso é o responsável pelo acompanhamento e execução do curso, tendo como objetivo principal gerenciar a oferta do curso nos pólos de ensino a distancia, indicando as necessidades do curso, adequação do mesmo para oferta aos alunos bem como de melhorias no financiamento. O coordenador de curso é a figura que formula as memórias de cálculo solicitando o financiamento de itens de grande importância para oferta do curso.

\section{3 - Coordenador de Tutoria}

A UAB visando a qualidade dos cursos ofertados e pelo aumento de alunos a cada semestre nos cursos sentiu a necessidade de financiar uma figura capaz de dar todo apoio e suporte aos tutores envolvidos em cada curso. O Coordenador de Tutoria é responsável por todo o formato de tutoria e por todos os tutores vinculados ao curso seja presencial ou a distância.

\section{4 - Tutores}

Tutor Presencial participante dos cursos e programas da UAB, selecionado pelas instituições vinculadas ao Sistema UAB, para o exercício das atividades típicas de tutoria em educação a distância, sendo exigida experiência no magistério ou formação pós-graduada. É valido informar que o tutor presencial na UAB é visto como um agente integrador, ou seja, a pessoa responsável por apoiar o aluno nas tarefas e demandas do curso. Esse política foi adotada tendo em vista a dificuldade de selecionar tutores presenciais em municípios interioranos, que correspondam as expectativas dos cursos ofertados. 
Tutor a Distância conforme a resolução deverá ser participante dos cursos e programas da UAB, selecionado pelas instituições vinculadas ao Sistema, para o exercício das atividades típicas de tutoria em educação a distância, sendo exigida experiência no magistério ou formação pós-graduada.

\section{5 - Professor Formador}

O professor formador é o responsável por ministrar as aulas presenciais e pelo acompanhamento da tutoria. O formador é aquele que tem como responsabilidade maior ensinar o aluno, para isso o mesmo deve elaborar planos de aula que de condições de melhoria no processo de ensino aprendizado para alunos e tutores. .

\section{6 - Professor Conteúdista}

È o responsável pela produção do material didático, seja ele em mídias ou em instrumento físico. Na resolução o professor conteúdista que atuará nas atividades típicas de ensino, de desenvolvimento de projetos e de pesquisa, relacionadas aos cursos e programas implantados no âmbito do Sistema UAB. Este professor também é conhecido como professor autor.

\section{7 - Revisor}

De acordo com Neder (2003), o material didático é o instrumento principal em EaD para manter o diálogo entre aluno e professor, assim ele deve ser pensado e concebido no interior de um projeto pedagógico e de uma proposta curricular definidas claramente. Neste sentido a UAB passou a financiar a figura do Revisor, cuja função seria em adequar o material produzido promovendo condições reais de oferta do curso. Toda a participação do revisor no processo de produção do material didático conta com a aprovação e colaboração do professor conteúdista ou seja o professor autor das disciplinas.

$$
8 \text { - Equipe Multidisciplinar }
$$


A equipe multidisciplinar foi introduzida no modelo de financiamento da UAB a partir das necessidades da IES em ofertar os cursos na modalidade a distância e das exigências que os cursos oferecidos e em específico os materiais didáticos solicitavam. Assim toda a produção do material pedagógico passa pela formatação e adequação para o formato multimídia, agregando diferentes possibilidades na apresentação do material didático.

Esta equipe conta com os profissionais da área de informática e as seguintes funções são indicadas: web designer, instrucional designer e diagramador.

Com a definição dos parâmetros a UAB começou a financiar os cursos seguindo estes padrões, sendo que cada IES tem sua especificidade e autonomia correspondentes, fincando complicado para o Sistema manter um padrão. O que se busca neste trabalho é a indicação de melhorias para o Sistema como um todo comparando instituições participantes na oferta de cursos comuns as mesmas. 


\section{3 - METODOLOGIA}

\section{1 - CARACTERIZAÇÃO DO PROBELAM DE PESQUISA}

A Educação a Distância - EaD vêm crescendo gradualmente entre a comunidade Acadêmica Brasileira, com apoio de políticas públicas que incentivam a criação de programas educacionais que permitem o crescimento desta modalidade de ensino. O sistema Universidade Aberta do Brasil - UAB, estimula a EaD, através de Instituições públicas de Ensino Superior - IPES , fomentando a oferta de cursos e interiorizando a educação.

Neste contexto busca-se o levantamento do referencial teórico sobre educação a distância, do Sistema UAB e dos custos de cada atividade envolvida no desenvolvimento das ações de fomento de cursos a distância. Convém relatar que muitas Instituições de Ensino buscam atuar com EaD, por visarem a possibilidade de ampliar o quantitativo de alunos, muitas vezes não se dando conta que o investimento necessário, seja ele em termos tecnológicos, de recursos humanos ou de infra-estrutura é muito alto. Convém destacar que o Sistema UAB financia as ações de custeio, ou seja, todas as despesas necessárias para realização do curso, contando sempre com a estrutura disponível nos pólo e nas Instituições deste infra-estrutura física a docentes (estes estimulados por bolsas).

As discussões sobre $\mathrm{EaD}$ no Brasil envolvem tanto questões pedagógicas quanto administrativas. No administrativo, ressalta-se a necessidade de analisar com maior precisão os custos envolvidos no desenvolvimento dos cursos. Sendo necessário buscar parâmetros de financiamento, com objetivo de ofertar curso superior público gratuito e de qualidade. O Problema a ser investigado consiste em identificar e propor um modelo de financiamento de cursos a distância no âmbito do Sistema UAB e de três instituições públicas de ensino superior participantes, com renomado conceito em EaD, no sentido de indicar melhorias no financiamento e contribuir com o desenvolvimento da educação no país.

Com o esclarecimento do problema da pesquisa, buscou-se o levantamento do referencial teórico nas áreas de educação a distância e custos. Em seguida, com uma pesquisa mais minuciosa, procurou-se localizar e estudar trabalhos que tratem de financiamento de cursos a distância.

Após a revisão da literatura e a determinação dos objetivos do trabalho, será abordado a criação de uma proposta de financiamento de cursos a distância, verificando as diversas 
ações e atividades necessárias ao financiamento do mesmo. Passando então a aplicar a proposta em um exemplo de curso no âmbito do Sistema UAB.

Esta é uma pesquisa de cunho exploratório cujo procedimento metodológico adotado para o seu desenvolvimento, no que se refere a coleta, análise dos dados e os meios de investigação, é o estudo de caso, bem como a pesquisa documental e bibliográfica. Esta mesma abordagem é citada por Vergara (2004, p.47) que afirma que esta pesquisa é realizada em área na qual há pouco conhecimento acumulado e sistematizado.

Segundo Gil (2002, p.41), o planejamento das pesquisas exploratórias é bastante flexível, de modo que possibilita a consideração dos mais variados aspectos relativos ao fato estudado, sendo que, na maioria dos casos assume a forma de pesquisa bibliográfica ou de estudo de caso.

Em relação ao método do estudo de caso, Vergara (2004, p.49) diz que este é circunscrito a uma ou poucas unidades, entendidas essas como pessoas, família, produto, empresa, órgão público, comunidade ou mesmo país, tendo caráter de profundidade e detalhamento, podendo ou não ser realizado no campo.

\section{2 - PROCEDIMENTOS PARA ANÁLISE}

Para realizar a pesquisa foi necessário escolher três Instituições Federais Ensino Superior - IFES, com vasta experiência em cursos a distância e participantes do Sistema UAB. O objetivo principal deste capítulo e detalhar as demandas de cada IPES para com cursos a serem ofertados. Os cursos a serem analisados são comuns às três instituições sendo o curso de Licenciatura em Pedagogia, Licenciatura em Física e Bacharelado em Administração todos de graduação.

Os cursos de pedagogia e administração forma escolhidos por serem bastante procurados e a demanda de vagas existentes aumentarem a cada ano. O curso de Física foi escolhido por possuir varias especificidades como a utilização de laboratórios e por se tratar de formação de professores.

O sistema UAB, financia os cursos anualmente assim as solicitações de cada IPES serão correspondentes a um ano de curso. As informações de cada IPES foram retiradas das Memórias de calculo encaminhadas por cada IPES referentes a cada curso ofertado. As instituições escolhidas são das regiões Sul, Sudeste e Centro-Oeste e serão identificadas como A, B e C para preservar as solicitações de cada uma. 


\section{4 - APRESENTAÇÃO E ANÁLISE DOS RESULTADOS}

\section{1 - DEMANDAS DE FINANCIAMENTO DAS IES PARCEIRAS DO SISTEMA UAB}

Neste Capitulo será descrito a pesquisa realizada com as 3 IES parceiras do Sistema UAB, buscou-se na analise dos dados parâmetros comuns ao Sistema UAB e as IES e solicitações diferentes entre os mesmo, tentando verificar a possibilidades de melhorias e de indicações para o fortalecimento do Sistema UAB.

As analises foram realizadas a partir do envio das memórias de calculo de cada curso pelas IES escolhidas, estas memórias são de fundamental importância para que o financiamento dos cursos em questão sejam analisados, apreciados e aprovados pelas coordenações do Sistema UAB.

Assim buscou-se relacionar as demandas das IES conforme as Ações de Financiamento adotadas pela UAB. Abaixo esta a descrição da pesquisa realizada com base nos dados enviados pelas IES.

\section{UNIVERSIDADE A}

A Instituição A justificou que para os cursos em questão as coordenações dos cursos e os professores responsáveis pelas disciplinas deverão realizar encontros presenciais, tanto no $1^{\circ}$ quanto no $2^{\circ}$ semestre, para as atividades iniciais e de encerramento das disciplinas, acompanhados pelo tutor à distância responsável pelo pólo. Além disso, pretende-se organizar um evento acadêmico com palestrantes convidados pela Coordenação do curso, o qual ocorrerá na Universidade, congregando os alunos de todos os pólos.

Foram previstas também:

- visitas dos tutores presenciais a IES para a realização de reuniões com os coordenadores de curso/ professores, podendo permanecer por 2 dias

- visitas dos Coordenadores dos pólos a IES e/ou coordenação curso no pólo para acertos sobre o andamento dos curso.

As postagens realizadas pela IES devrão ser em 2 Remessa de volumes com materiais para cada um dos pólos, durante o $1^{\circ}$ semestre e $2^{\circ}$ semestre, a um custo de $\mathrm{R} \$ 50,00$ conforme parâmetro da UAB. 
A Contratação de pessoa física se dará em forma de bolsa, de secretaria de curso e pessoal de apoio para a equipe multidisciplinar por 12 meses pois possuimos dificuldades na contratação de pessoal pois a mesma deverá ser via concurso público.

A contratação de Serviços de terceiros pessoa Juridica em virtude da Universidade não dispor de viaturas suficientes para atender às necessidades de deslocamento dos docentes para a realização de encontros presenciais, e dada a inviabilidade destes professores chegarem aos pólos de ônibus, face a estes pólos situarem-se em locais de difícil acesso, faz-se necessária a contratação de serviços terceirizados para transporte dos docentes aos pólos.

Cabe salientar que estes docentes atuam também nos cursos presenciais da Instituição, portanto seu tempo de deslocamento deve ser minimizado.

Para as avaliações presenciais, que serão aplicadas pelos tutores a distância, o deslocamento será feito por meio de ônibus.

No primeiro semestre está previsto um evento que visa agregar os alunos de todos os pólos na UAB, com palestras e seminários. Este evento tem caráter motivador e instigador para a pesquisa. Também serão necessários recursos para sua organização. $\mathrm{R} \$ 5.000,00=$ Organização do evento no terceiro semestre reunindo todos alunos dos pólos e outros serviços especializados.

As outras Ações de financiamentos seguiram os padrões do Sistema UAB, foi solicitado pela IES que a seleção e capacitação não fosse incluido no modelo de financiamento.

\section{UNIVERSIDADE B}

A instituição justificou que são necessários no mínimo 2 visitas por disciplina.sendo 6 disciplinas por semestre e 12 disciplinas ao ano. No total 24 visitas/ano ao pólo para encontros presenciais visando à verificação in loco da aprendizagem e realização dos exames presenciais. Por disciplina, a primeira visita contará com três pessoas (um professor e dois tutores) e a segunda com duas (professor e tutor).

Quanto a aquisição de bibliografia o idealpara consulta dos tutores e professores seriam no mínimo de 3 livros por disciplina no valor médio de cada livro R\$150,00

A IES solicitou algo que foge dos parâmetros do Sistema que é a divulgação do curso será realizada com os materiais relacionados a seguir: Banners, Cartazes, Folders, Blocos personalizados, Canetas personalizadas, Bolsa personalizadas, Camisas personalizadas. 
Quanto a serviços Serviços de Terceiros - Pessoa Jurídica a IES solicitou a contratação de empresa especializada em fornecimento de mão-de-obra especializada em secretariado (organização de arquivos, atendimento aos alunos e professores, controle de material e tarefas afins). Para a organização e realização do processo seletivo será necessário a constituição de uma banca de avaliação, composta por um coordenador e dois professores de letras/português.

Quanto as Bolsas a solicitação foi a seguinte: para Professores/Pesquisadores: Serão necessários 24 professores, 48 tutores e um coordenador do curso 18 professores atuarão por um mês, cada um, mais quatro meses de capacitação. Seis professores atuarão por dois meses, cada um, mais quatro meses de capacitação. O coordenador de Curso atuará durante todo o ano letivo. Os tutores a distância serão 3 para cada 50 alunos atuando por 12 meses cada. Os tutores presenciais a necessidade de 2 por pólo por curso.

As outras Ações de financiamentos seguiram os padrões do Sistema UAB, sendo que a IES solicitou que fosse feito um projeto de cpacitação continuada par todos os profissionais atuantes no Sitema.

\section{UNIVERSIDADE C}

A Instituição justificou que serão necessários no mínimo 5 visitas aos Pólos para avaliação inicial e andamento das solicitações de melhorias. Com pagamento de diárias e combustíveis. Sendo necessário a realização de 6 visitas por semestres aos pólos para encontros presenciais visando à verificação in loco da aprendizagem, avaliação e realização dos exames presenciais.

Quanto aos serviços de terceiros pessoa física foi solicitado: secretária para atendimento a professores, tutores e alunos e auxílio nos trâmites internos da instituição; apoio para preparação e organização de documentos, arquivos e relatórios e controle internos; estagiário para atendimento e solução de problemas na plataforma de ensino aos alunos; estagiário para atendimento aos professores e tutores quanto ao uso de ferramentas e disponibilização de material e/ou aplicativos aos alunos.

A solicitação para serviços de terceiros pessoa jurídica foi: locação de Bens Móveis aluguel de carro para deslocamento aos pólos; hospedagem - estada nos pólos da equipe que viaja; contratação de filmagem para encontro presencial. 
Quanto aos tutores a Instituição C tem a figura do tutor como um tutor como um profissional extremamente valorizado pela devido ao trabalho de orientação e acompanhamento do aluno durante o seu processo de aprendizagem nas disciplinas dos cursos que participa. Para tanto, é necessários assessorá-lo no desenvolvimento de estratégias de acompanhamento e gerenciamento do processo de ensino-aprendizagem, tendo por foco as formas de interação a distância e o uso dos ambientes virtuais utilizados. A IES Busca, desta maneira, desenvolver a formação de uma tutoria virtual participativa, questionadora e parceira do professor coordenador da disciplina na formação do estudante. Desta forma a IES necessita de 3 tutores para cada 50 alunos.

As demais solicitações da IES foram atendidas pelos parâmetros do Sistema.

\section{2 - ANÁLISE DOS DADOS}

Ao analisar os dados ficou claro que as Ações de financiamento da UAB contemplam as demandas das IES, sendo que os parâmetros usados na UAB na visão das 3 instituições analisadas não são suficientes para que os cursos tenham um bom andamento. As maiores divergências encontradas nesta situação são as quantidades de visitas disponíveis, os valores do material de consumo e o quantitativo de bolsas. Tendo em vista que o objetivo desta pesquisa é propor melhorias para o modelo de financiamento do Sistema e verificar as condições e propostas definidas por cada IES foi relacionado os elementos mais relevantes da pesquisa que poderão de alguma maneira influenciar direta ou indiretamente nas Ações da UAB.

A produção do material didático é para a modalidade de Educação a Distância o ponto fundamental para o aprendizado do aluno, pois o mesmo é o meio físico e presencial do curso. A UAB financia para a produção dos materiais bolsas para professores pesquisadores e conteúdistas, com intuito de proporcionar ao curso um material acessível para todos os alunos, além de financiar uma equipe multidisciplinar que dará todo apoio e recursos tecnológicos necessários para produção seja dos materiais impressos quanto dos materiais midiáticos.

Segundo Neder (2000,p.208) o material didático do curso, no âmbito da proposta curricular, configura-se como um dos dinamizadores da construção curricular e também como um balizador metodológico. É através do material didático que são feitos os recortes das áreas de conhecimento trabalhadas no curso 
Foi comum entre as IES que o material didático tem papel fundamental na proposta pedagógica do curso. Estes deverão conter em sua estrutura, recursos dinamizadores para o desenvolvimento da proposta curricular, tendo em vista que é o principal facilitador da interlocução entre educadores e educandos, mediando, portanto, o processo de aprendizagem.

Foi comum também que para o desenvolvimento dos cursos e do material didático será elaborado por uma equipe multidisciplinar de docentes que atuarão no curso, e serão basicamente compostos por: livros textos, guias de estudos, livros de apoio didático, artigos, cd’s, vídeos e vídeo-conferências.

Os livros textos da IES A conforme analise serão elaborados pelos integrantes da Equipe Multidisciplinar e docentes do curso, com o objetivo de facilitar o aprendizado do aluno, garantindo o desenvolvimento dos conteúdos programáticos essenciais e a instrumentalização do processo ação-reflexão.

A produção de um guia de estudo, com orientações sobre como utilizá-lo, atividades pedagógicas verificadoras da aprendizagem, exercícios de fixação e textos para aprofundamento teórico foi demandado por todas as IES. Justificando que em cada disciplina, como enriquecimento teórico ou metodológico e ainda como forma de dinamizar as discussões, serão indicados tanto artigos de periódicos especializados como artigos de revistas e jornais de caráter geral, virtuais ou não.

A produção e reprodução de cd's são comuns a todas as IES, sendo que a IES C informou que os cd's serão produzidos especialmente para os cursos, contendo textos complementares, bibliografia comentada, animações e vídeos para facilitar a compreensão de alguns tópicos. Os CD’s trarão seções de dúvidas e diversos links para o acesso à internet, estimulando o contanto via rede.

A IES B fez uma importante observação quanto as vídeo conferencias, já que o Sistema UAB não financia os pólos e estes devem manter uma estrutura apropriada para oferta dos cursos. Conforme financiamento do Sistema e definição das IES, serão produzidos Vídeos e Vídeo-conferências onde os pólos deverão ser equipados com uma videoteca e sala de recepção. Para as atividades recomendadas como material complementar pelos professores, serão utilizados vídeos educativos.

Quanto a dificuldade na contração de pessoal, falta de docentes na IES e tendo em vista a abrangência do programa e as dificuldades que as IES já enfrentam com o crescimento do Sistema UAB devido a grande demanda por cursos, os docentes nas IES realizarão na UAB um trabalho adicional remunerado com bolsas. 
Hoje os docentes continuam em seus Institutos e Faculdades de origem, desenvolvendo atividades didático-pedagógicas e administrativas no âmbito da UAB. Os docentes, na maioria das vezes, acumulam atividades em seus departamentos de origem e na UAB, pois é difícil disponibilidade oficial para se dedicarem aos cursos da UAB.

IES A está discutindo nos Colegiados Superiores uma nova política de oferta de cursos a distância e uma re-organização do sistema de $\mathrm{EaD}$, nos moldes do que vem sendo implementado pelo MEC por meio da UAB. Pois, até 2007, os cursos a distância eram coordenados e desenvolvidos pelo Núcleo de Educação a Distância, no Instituto de Educação. Hoje, há necessidade de nova estrutura, no interior da IES A, para oferta de cursos. Nesse sentido, foi encaminhado projeto de Institucionalização da UAB na IES A e o projeto de construção de sede própria, que deverá ser entregue até maio de 2009.

Assim para que as unidades acadêmicas não tenham prejuízo global de suas atividades de ensino e pesquisa, viabilizando o trabalho adicional na UAB, a previsão de serem disponibilizadas 2.000 vagas para docentes, em 3 anos, para aquelas unidades acadêmicas das IFES e CEFET's que estiverem ofertando cursos através da UAB.

Para que as IFES e CEFETs possam cumprir com o papel de gestor do processo (produção e entrega de material didático, avaliação presencial, seleção e administração de tutores, etc) a previsão de serem disponibilizadas 1000 vagas de técnico-administrativos para os centros de educação a distância destas Instituições.

Quanto ao pagamento de bolsas no Sistema UAB verifica-se a necessidade de estabelecer que a quantidade de docentes a receberem bolsas em cada curso deverá ser definido no projeto político- pedagógico do curso, em função de parâmetros pré-definidos pela UAB, e consolidado na planilha de financiamento do curso acordada entre o MEC e a IES. Quanto a Seleção, a Instituição B indica que cada IES deve desenvolver diretrizes institucionais para estabelecer um processo público de seleção interna dos docentes que devem participar do projeto. A UAB recomenda a criação de um regimento interno para cada curso, com previsão de eleição para coordenador de curso.

A Universidade Aberta do Brasil - UAB estabelece em seu modelo educacional, a existência de tutores presenciais e a distância, professores e coordenadores. A orientação dada as Universidades integrantes do Sistema UAB é que cada uma delas elabore um entendimento da estrutura e organização do sistema de ensino e aprendizagem considerando tais agentes e considerando a utilização de ambientes computacionais em rede para dar apoio ao processo de ensino aprendizado. 
Quanto a formação continuada de tutores nota-se uma preocupação em comum entre as IES onde há um grande esforço estratégico dos supervisores e coordenadores de curso para que uma vez que os tutores tenham a formação inicial, sejam reaproveitados no máximo de disciplinas possível.

A Instituição A indica que apesar do esforço de manter os atores capacitados é muito difícil, pois a cada trimestre várias disciplinas que demandam grande especificidade de conhecimento por parte dos tutores são iniciadas, o que nos exige a re-oferta do curso de formação inicial de tutores. Além disso, há vários que desistem da tutoria por diferentes motivos e cujas vagas precisam ser respostas, reafirmando a necessidade dos cursos de formação de tutores.

Para os tutores que estão atuando, a Universidade C coloca que há a necessidade de oferecer formações continuadas que contemplem temáticas que possibilitem maior qualidade no atendimento ao aluno, tornando-os tutores melhor preparados para atuar em suas funções. Alguns temas propostos são: sistema de avaliação, liderança e gestão de grupos, uso do Sistema de Organização de Feedback, Interações e Avaliações, técnicas de análise transacional, dentre outros.

A Universidade B mostra-se também preocupada com a Gestão dos Pólos de apoio presencial onde constatam que a falta de capacitação para o desempenho de funções específicas - como membro de uma equipe multidisciplinar - responsável pela gestão do pólo - se apresenta como um complicador nas relações entre pólos - municípios- estudantes-cursos - universidade.

Essas dificuldades, claramente expressas e compartilhadas pelas IES no Fórum de coordenadores de área onde um conjunto de coordenadores, refletem sobre o andamento das atividades pedagógicas propostas pelos cursos e, muito especialmente, no grau de satisfação dos estudantes frente aos espaços/tempos destinados aos estudos nos pólos de apoio presencial.

Aqui, importa frisar que muitas das problemáticas vividas por coordenadores, equipe multidisciplinar e estudantes demonstram, muitas vezes, a ausência de compreensão acerca das representações sociais, políticas e econômicas atribuídas aos pólos no canário local e regional. Nesse sentido, muitas vezes, a gestão do pólo se vê atravessada por interesses políticos que em nada tem a ver com os interesses educacionais e as expectativas das comunidades.

Hoje a escolha do coordenador de pólo é realizada por indicação do prefeito tornandose um cargo político dentro do município, a Instituição levanta este ponto e propõe que a 
seleção dos coordenadores de pólo de apoio presencial: seja realizada, dentro de parâmetros e perfis definidos pelo MEC e em conjunto pelas IES que participam da UAB e oferecem cursos nos pólos.

Assim a UAB entende que a gestão de pólo exige a preparação para o desempenho de suas funções especificas como sujeitos partícipes de uma equipe multidisciplinar (bibliotecários, técnicos em informática, secretários). Assim, temas como gestão educacional; plano de gestão para o pólo; planejamento e avaliação das atividades; registro acadêmico, infra-estrutura de serviços, recursos tecnológicos e outros se tornam imprescindíveis para a qualificação que garantam o sucesso dos processos formativos dos cursos na modalidade da EAD, se constituindo em elemento propulsor do desenvolvimento local-regional. 


\section{5 - CONCLUSÃO}

A educação a distância não é somente uma nova proposta educacional-pedagógica, é também, uma forma de inserção na sociedade tecnológica que se faz existir a partir do uso de novos instrumentos. A EaD é percebida, como uma forma dinâmica de ensino, que possibilita a auto-aprendizagem através de diversos recursos didático-pedagógicos organizados, estruturados e apresentados em diferentes suportes de informação, que podem ser utilizados isoladamente, ou ainda de forma combinada, veiculados pelos diferentes meios de comunicação. Desta forma, a UAB surge como uma possibilidade de alavancar o processo de ensino-aprendizagem em Municípios onde não existe ensino superior público.

Pela pesquisa verifica-se a necessidade do Sistema UAB rever todo o processo de financiamento utilizado hoje, pois a cada momento as instituições mudam a forma pela qual vem agindo. Assim a UAB deverá dar fundamental importância ao planejamento de estratégias de acompanhamento e avaliação em EAD, como forma de antecipar as estratégias de prevenção e de controle da evasão. Para isso a UAB deverá estimular e compreender os vários possíveis motivos de evasão, em cada uma das etapas do processo de EAD. Assim a CAPES deve criar uma linha de pesquisa específica para as atividades de EAD, criando no seio da academia uma base teórico-metodológica de atividades independentes de avaliação visando ao aprimoramento da área em geral;

É necessário salientar também as dificuldades encontradas no decurso do trabalho em especial na coleta de dados. Portanto, os dados coletados e expressos neste trabalho, são dados escritos presentes em documentos. Nesse sentido a pesquisa é documental, não se preocupando com a forma com que esses dados foram aplicados ou remanejados na prática, para a concretização dos períodos em estudo.

Acredito que o presente trabalho, torna disponíveis informações sobre a Educação a Distância, em especial sobre o Sistema UAB. 


\section{REFERÊNCIAS}

BELLONI, Maria Luiza. Educação a Distância. Campinas: Autores Associados, 1999.

BRASIL, MINISTÉRIO DA EDUCAÇÃO. Lei de Diretrizes e Bases da Educação Nacional, n. 9.394/96.

DECRETO n. 5.622/05. Disponível em: http://www.planalto.gov.br/ccivil_03/_Ato20042006/2005/Decreto/_quadro.htm . Acesso em 12/04/2008

CASTRO, Claudio de Moura. A equação da EAD. In: Congresso Internacional de Educação a Distância, 8., 2001, Brasília

DECRETO n. 5.800/06. Disponível em: http://www.planalto.gov.br/ccivil_03/_Ato20042006/2005/Decreto/_quadro.htm . Acesso em 12/04/2008

LITWIN, Edith (org.) Educação a Distância: temas para o debate de uma nova agenda educativa. Porto Alegre: Artmed, 2001, 110p.

MORAN, José Manuel. Avaliação do Ensino Superior a Distância no Brasil. Disponível em: http://www.eca.usp.br/prof/moran/textosead.htm . Acesso em 14/03/2008

MUNDIM, Kleber Carlos. Ensino a distância no Brasil: problemas e desafios. In: BRASIL, MINISTÉRIO DA EDUCAÇÃO. Desafios da Educação a distância na formação de professores. Brasília, Secretaria de Educação a Distância, 2006, p.119-126

NEDER, Maria \& PRETI, Orestes. Pedagogia na Modalidade Licenciatura para os anos

Iniciais do Ensino Fundamental. 3 ed. rev. mod. Cuiabá, NEAD/IE-UFMT, 2003. 102p.

PRADO, Maria Lígia Coelho Prado. [Artigo]. Folha de São Paulo. São Paulo, 20 jun. 2000.

Caderno Especial, p. 5.

PRADO, Maria Lígia Coelho Prado. [Artigo]. Folha de São Paulo. São Paulo, 20 jun. 2000. Caderno Especial, p. 5.

PRETI, Oreste (org.). Educação a distância: inícios e indícios de um percurso. Cuiabá: NEAD/IE - UFMT, 1996. 188 p.

PRETI, Oreste (org.). Educação a distância: construindo significados. Cuiabá: NEAD/IE UFMT, Brasília: Plano, 2000. 268 p.

TOMMASI, Marcelo. Custeio Gerencial - Conceituação, Considerações e Perspectivas. In:

UNESCO. Aprendizagem aberta e a distância: perspectivas e considerações sobre políticas educacionais. Florianópolis: UFSC, 1998. 81 p 


\section{ANEXO I}

PLANILHA DE FINANCIAMENTO UAB 